Seminário de Pesquisa

Programa de Pós-Graduação

Design FAU USP

\title{
Processamento de dados e análise em estudo histórico- etnográfico com diferentes fontes de dados
}

\author{
Maria do Rosário Gonçalves Mira, Luís Cláudio Portugal \\ do Nascimento
}

método; design; sociologia do design; história do design; sociedade

Este resumo descreve parte do método e estratégias de coleta e tratamento de dados, utilizadas em pesquisa de doutorado, de estudo histórico-etnográfico, que se ocupou da questão: Que transformações sociológicas foram possibilitadas pelo advento da tecnologia e pela introdução dos materiais plásticos no contexto do design de produto e quais as naturezas destas transformações? Foram adotadas como parte das técnicas de coleta de dados: entrevistas semiestruturadas em profundidade com especialistas,

\section{Curso}

Doutorado

\section{Linha de Pesquisa}

Teoria e História do Design

\section{Maria do Rosário Gonçalves Mira} Doutoranda em Design, pelo PPG Design, na Universidade de São Paulo; Mestre em Arquitetura e Urbanismo, área de concentração Design e Arquitetura, na Universidade de São Paulo (2016). Bacharel em Design Industrial desde 2005 pelo UniFMU, SP. e-mail: mariarosariomira@usp.br Lattes: http://lattes.cnpq. br/8534318501248974

Orcid: https://orcid.org/00000002-5814-0319

\section{Luís Cláudio Portugal \\ do Nascimento}

Professor da Fau-usp, doutor em ensino do design pela New York University (1997),mestre pela École Nationale Supérieure d'Arts et Métiers, Paris (1987), e bacharel em desenho industrial e comunicação visual pela Escola Superior de Desenho Industrial da Uerj (1983).

e-mail: claudioportugal@usp.br

Lattes: http://lattes.cnpq. br/2797773827825547

Orcid: https://orcid.org/00000003-4586-1747 designers, historiadores (no Brasil e Itália); revisão da literatura pertinente (ao campo do Design, da Engenharia de Materiais, Tecnologia e da Sociologia), bem como visita a coleções de museus, catálogos de empresas, coleta de anúncios publicitários e de imagens de produtos. Como técnica de tratamento de dados, utilizou-se a técnica da análise associativa dos dados, que consistiu de processo indutivo de identificação de eixos temáticos a partir de exame analítico em meio ao conjunto de dados brutos coletados, fragmentados, indexados e sistematizados. Foram então associadas neste processo as imagens de produtos, anúncios publicitários, bem como a associação dos dados levantados a partir da literatura revisada, que permitisse associação aos subproblemas da pesquisa. Os dados foram analisados em primeiro momento em separado e depois reunidos na seção pertinente aos resultados de cada subproblema. Após esta etapa, sofreram novo e profundo processo de análise por meio de interações entre os resultados dos três subproblemas da pesquisa com o objetivo de responder à pergunta fundamental da pesquisa. 


\title{
Data processing and analysis in historical-ethnographic study with different data sources
}

\author{
Maria do Rosário Gonçalves Mira, Luís Cláudio Portugal \\ do Nascimento
}

\section{method; design; sociology of design; history of design; society}

This summary describes part of the method and strategies for data collection and processing applied in this doctoral research of historical-ethnographic type, which addressed the question: What sociological transformations have been made possible by the advent of technology and the introduction of plastic materials in the context of product design, and what are the nature of these transformations? The following were adopted as part of the data collection techniques: semi-structured in-depth interviews with specialists, designers, historians (in Brazil and Italy); literature review (in the field of Design, Materials Engineering, Technology and Sociology), as well as visits to museum collections, catalogues of companies, collection of advertisements and product images. In order to process data it was used the technique of associative data analysis, which consisted of an inductive process of identification of the thematic axes derived from analytical examination in the midst of a set of raw data which was collected, fragmented, indexed and systematised. This process gathered product images, advertisements, as well as the association of the data collected from the revised literature, which allowed for association with the subproblems of the research. The dataset were analysed separately and then gathered in the section pertinent to the results of each subproblem. After this stage, they underwent a new and profound process of analysis through interactions between the results of the three subproblems of the research in order to answer the fundamental question of the research.

\section{Referências | References}

GIBBS, G. 2009. Análise de dados qualitativos. Tradução Roberto Cataldo Costa. Porto Alegre: Artmed.

ADAM, J. M.; HEIDMANN, U.; MAINGUENEAU, D. 2018. Análises textuais e Discursivas: Metodologia e aplicações. São Paulo: Cortez.

CRESWELL, J. W. \& LOPES, M. F. Tradutor Dirceu da Silva. 2014. Projeto de pesquisa - Métodos qualitativo, quantitativo e misto. Rio de Janeiro: Penso

\section{Luís Cláudio Portugal \\ do Nascimento}

Professor at Fau-usp. He holds a

PhD in art education from New

York University (1997), a Masters

Degree from École Nationale

Supérieure d'Arts et Métiers, Paris (1987), and a Bachelors Degree in Graphic and Industrial Design from Uerj's Escola Superior de Desenho Industrial.

e-mail: claudioportugal@usp.br

Lattes: http://lattes.cnpq. br/2797773827825547

Orcid: https://orcid.org/0000-

0003-4586-1747 